\title{
European Direct Investment in Brazil, 1860 to the Present
}

\author{
Sérgio de Oliveira Birchal \\ Âmara Fuccio de Fraga e Silva
}

\section{Introduction}

European direct investment in Brazil dates back to the discovery of the country and has been since then either hegemonic or more important than a superficial observation can grasp, as this work aims at showing. During the $20^{\text {th }}$ century, the United States has replaced Britain as the world's economic superpower and the largest direct investor. US dominance in the world economy and geographical proximity to Brazil would suggest that US investments were by far the largest in the country during that century. Furthermore, as Japan had become the second largest economy in the world in the 1980s, we would expect that this would be reflected in the data of the largest multinationals in Brazil. However, as our investigation suggests, Western European direct investment has been as large (and in many occasions even larger) as that of the USA and Japanese firms have never had a prominent presence among the largest firms in Brazil, at least until the late 1990s.

\section{From the mid-1800s to the $2^{\text {nd }}$ World War}

The beginning of the $20^{\text {th }}$ century marks a time of large transformations in the world economy with diffusion of the $2^{\text {nd }}$ Industrial Revolution and its productive, financial, and organizational related changes. The new industrialized countries, such as the USA, Germany, and Japan, began to challenge (and gradually surpass) British world industrial hegemony ${ }^{2}$. In the first decades of the $20^{\text {th }}$ century, Germany and the USA transformed themselves into net exporters of capital to the rest of world, for the first time. These countries were also competing in new markets and in those traditionally monopolized by the British ${ }^{3}$. As the most developed economies were rapidly recovering from the Great Depression of the $19^{\text {th }}$ century ${ }^{4}$, DFI was starting a new lending cycle to developing countries (DCs) ${ }^{5}$.

In Brazil DFI was not only substantially larger when compared with that of the second half of the $19^{\text {th }}$ century ${ }^{6}$, but also more diversified in terms of sectors. Furthermore, although Britain continued to lose its relative participation, Britain and France alone were responsible for $60 \%$ of the total DFI invested in Brazil, being by far the largest foreign investors in the country. Although, North American direct investment was growing fast in the decade from 1903 to 1913 (US and Canadian participation grew from $3.8 \%$ in the 1860 s to $30 \%$ in the $1910 \mathrm{~s}^{7}$ ), up to 1914 US investment was much heavier in the neighbouring Mexico and Central

\footnotetext{
${ }^{1}$ Doutor pela London School e Professor do IBMEC - MG

${ }^{2}$ See, among others, C. Freeman and L. Soete, The Economics of Industrial Innovation, Cambridge MA: MIT Press, $3^{\text {rd }}$ ed. 1997; A.D. Chandler, Jr., The Visible Hand: The Managerial Revolution in American Business, Cambridge, MA: Harvard University Press, 1977; K. Polanyi, The Great Transformation: The Political and Economic Origins of our Time, Beacon Press, $2^{\text {nd }}$ ed., 2001 and D.S. Landes, The Unbound Prometheus: Technological Change and Industrial Development in Western Europe from 1750 to the Present, New York: Cambridge University Press, 1969.

${ }^{3}$ Castro, As Empresas Estrangeiras no Brasil, 1860-1913, p. 90.

${ }^{4}$ Hobsbawm, A Era dos Impérios, 1875-1914, pp.73-8.

5 As observed by Manzocchi, "the most broadly accepted description of a typical lending cycle to DCs is: "Let us start from the recovery phase, when capital flows move again into DCs after a period of scarcity. This phase is commonly associated with a combination of 'push' and 'pull' factors (...) Finally, the conditions of financial and economic activity in the Western (core) economies are frequently suggested as major determinants of a recovery in foreign lending to DCs. (...) The final stage of the international gold standard before the First World War witnessed a new upturn in capital flows, in both absolute and relative terms, which led to the highest ratio of gross foreign capital to GDP in developing economies". Manzocchi, Foreign Capital in Developing Economies: Perspectives from the Theory of Economic Growth, , pp.11-7.

${ }^{6}$ Castro, As Empresas Estrangeiras no Brasil, 1860-1913, pp. 90, 97.

${ }^{7}$ Castro, As Empresas Estrangeiras no Brasil, 1860-1913, p. 102.
} 
America. In Brazil, French and British direct investment far exceeded US investments ${ }^{8}$. In terms of sectors, railways were still largely dominated by British capital, although the sector was going through a rapid process of consolidation with the merger of individual railways. However, the most important investment, in quantitative terms, was in other public services, more specifically, in urban transport and electrification. As observed by Castro, foreign investment in electricity was vital to the industrialization of the period, due to the incapacity of the Brazilian private sector to raise the necessary funds to make these investments. Furthermore, the existence of an industrial sector in the country demanding these kind of services was an important factor behind the interest of DFI in Brazil, which otherwise would not be as substantial. The boom in the construction sector in first years of the $20^{\text {th }}$ century, following the growth of many Brazilian cities, also attracted a large number of foreign companies to the sector, mainly British. In banking, German, French, and Belgium capitals have increased their participation. British and US firms divided the mining sector, although the sector represented only $4.3 \%$ of total DFI invested between 1903-1913. However, investment in mining was changing from precious metals to ore and other ferrous metals, forming the basis for the future growth of the steel-making industry in the country. In the import and export-sector, the effort of different countries to establish their commercial basis in the country resulted in the diversification of the DFI in the sector. British firms controlled more than $60 \%$ of rubber commercialisation, although two large US firms were established in 1912 (Guaporé Rubber Co., the largest in terms of capital, and Goodyear Tire Rubber Co of South America). Among the British companies is worth mentioning the establishment of The Dunlop Pneumatic Tyre Co. ${ }^{9}$ during these years.

The rapid industrial development in the most industrialized countries in the 1903-1913 period was followed by the invention of a large variety of new products, a number of them science-based, requiring increasingly larger scales of production and distribution, growing mass markets, sophisticated management structures, and big internationalised companies ${ }^{10}$, clear "push" factors. Thus, whenever import tax barriers, costs of transport and other reasons turned the export of industrial production more profitable, these internationalised big firms were willing to establish in countries where there was an established domestic market, a clear "pull" factor behind these investments. They tend to establish commercial representative offices and, later on, the assemblage of products ${ }^{11}$.

In 1896, for example, Bayer (the chemical German firm) appointed a representative in Brazil, but in 1911 it set up its own commercial office in Rio de Janeiro ${ }^{12}$. In the early $20^{\text {th }}$ century, Royal Dutch Shell expanded with acquisitions in Europe, Africa and Americas, propelled mainly by "push" factors: "These were exciting times for the oil industry, as the mass production of cars had open up a vast new market"" . In Brazil, Shell began distributing gasoline and kerosene in $1913^{14}$. Siemens also set up a commercial office in Rio de Janeiro in 1895 and in 1905 the company was established, although manufacturing had started only in $1938^{15}$. In other opportunities foreign capital just acquired established domestic firms. In 1903, a Portuguese immigrant (Albino Souza Cruz) was the first to produce machine-made cigarettes in Brazil. The innovation eliminated the work to separate and stretch the straw, to cut the cord tobacco, and to roll the cigarette. However, demand soon surpassed production capacity and Souza Cruz bought another tobacco firm. However, in 1914, due to

\footnotetext{
${ }^{8}$ R. Grosse, Multinationals in Latin América, London: Routledge, 1989, p.11.

${ }^{9}$ Ibid., pp.104-6.

${ }^{10}$ See Chandler, Jr., The Visible Hand: The Managerial Revolution in American Business.

${ }^{11}$ Castro, As Empresas Estrangeiras no Brasil, 1860-1913, pp.106-7.

12 www.bayer.com.br, A Empresa no Brasil.

13 www.shell.com, History of Shell.

${ }_{14}^{14}$ Ibid., História da Shell no Brasil.

15 www.siemens.com.br, Our Plant.
} 
technological reasons, Souza Cruz was forced to sell the company to British American Tobacco (BAT) ${ }^{16}$.

Thus, in the period before the $1^{\text {st }}$ World War Western European direct investment was still by far the largest in Brazil, although North American investment was growing fast. Furthermore, multinational firms were also changing from the "standing by firm" form to the multidivisional and managerial form.

Despite the acquisition of Souza Cruz by BAT in 1914, the $1^{\text {st }}$ World War disrupted almost every aspect of the world economy ${ }^{17}$, bringing the flow of DFI to Brazil nearly to a halt. With the risks involved in the maritime transport and the need to produce goods for the War efforts, multinationals concentrated their attention in their countries of origin ${ }^{18}$, most of which were involved in the War.

Although the immediate years following the end of the $1^{\text {st }}$ World War was marked by a severe recession, especially in Britain and Japan, there were sufficient continuities with the pre-War economy which provided a favourable climate for DFI expansion. The rapid industrialization in the USA, Australia, Canada, Brazil and India, among other countries, represented important opportunities for DFI, as world trade recovered in the $1920 \mathrm{~s}^{19}$. The dynamism of the Brazilian economy in the 1920s was largely due to the rapid expansion of the coffee sector. The favourable situation of the balance of payment during the 1920s caused the valorisation of the local currency, which, combined with the rise of the local prices, diminished any protection that the domestic industry had against foreign competitors ${ }^{20}$. Thus, the combination of "push" and "pull" factors brought a renewed flow of DFI to Brazil during the 1920s.

Although the growth of the textile industry was extremely slow, other industrial sectors grew much more rapidly in the 1920 s, followed by a notable tendency of industrial diversification $^{21}$. As observed by Gonçalves, from the 1920s on, DFI had an important role both in the expansion of the industrial production in Brazil and in the diversification of the industrial structure of the country ${ }^{22}$. Multinationals were now investing mainly in the industry, as opposed to public services and infrastructure, the main sectors of FDI during the $19^{\text {th }}$ century. Therefore, in the inter-war years multinationals invested in several industrial sectors in Brazil, such as paper, tobacco, matches, textiles, shoes, food, railway equipment, bulbs, transformers, domestic appliances, automobiles, paper bags, metallurgy, cement, glass, chemical and pharmaceutical products ${ }^{23}$. The industrial diversification of the 1920s has been currently attributed to several reasons, among them, government exception of import taxes over equipments and subsidies ${ }^{24}$.

Western European firms were among the leaders in several of these sectors. In 1920, in the tobacco industry, Souza Cruz expanded vertically its production in the country, with the establishment of its first plant to benefit tobacco, in the state of Rio Grande do Sul, and the acquisition of a lithograph firm, in Rio de Janeiro ${ }^{25}$. Furthermore, in 1923 Souza Cruz began to build the largest cigarette factory in Latin America ${ }^{26}$, opening up the way to its leadership

\footnotetext{
${ }^{16}$ www.souzacruz.com.br, Perfil Souza Cruz.

${ }_{17}$ Jones, The Evolution of International Business: An Introduction, p. 38.

${ }^{18}$ Pereira, Multinacionais no Brasil: Aspectos Sociais e Políticos, p. 28.

${ }^{19}$ Jones, The Evolution of International Business: An Introduction, p. 38.

${ }^{20}$ Baer, A Economia Brasileira, p. 48 .

${ }^{21}$ Ibid., p.48.

${ }^{22}$ Gonçalves, Globalização e Desnacionalização, p.53.

${ }^{23}$ Ibid., pp.55-6.

${ }^{24}$ Baer, A Economia Brasileira, p. 48.

${ }^{25}$ www.souzacruz.com.br, Perfil Souza Cruz, p.1.

${ }^{26}$ W. Baer, A Industrialização e o Desenvolvimento Econômico no Brasil, São Paulo: Difel, 1975, In: A.C. Lacerda, J.I. Bocchi, J.M. Rego, M.A. Borges, and R.M. Marques, Economia Brasileira, São Paulo: Saraiva, 2001, p.50.
} 
in this industry in Brazil. In 1920, the French company Rhodia built its first plant in Brazil to produce chemical products. Nine years later, Rhodia established itself in the textile sector through the Companhia Brasileira de Sedas Rhodiaseta, producing artificial threads ${ }^{27}$, a diversification strategy to exploit economies of scope. In 1921, Bayer founded the Chimica Industrial Bayer Weskott \& Cia., which besides importing and commercialising products from the parent company, began the local production of medicines ${ }^{28}$. Four years later Bayer founded the company Aliança Comercial de Anilinas to commercialise dyes produced in Brazil and imported from Germany ${ }^{29}$, also a strategy of related diversification. In 1921 also, the Companhia Siderúrgica Mineira, the first integrated steel-making mill, founded by a group of Brazilian engineers, was acquired by ARBED, from Luxembourg, which created the Companhia Siderúrgica Belgo-Mineira. Over the 1920s, the new company invested in the growth of the productive capacity of its mill in Sabará, Minas Gerais ${ }^{30}$. In the food industry, Nestlé was authorized by a presidential decree, published on 11 January 1921, to start operating its Brazilian plant in the city of Araras, São Paulo ${ }^{31}$. In 1924, the Dutch company Philips opened its first commercial office in Brazil to import bulbs and, in the following years, radios $^{32}$. In 1926, the Swedish company Electrolux was established a commercial office in São Paulo ${ }^{33}$. Finally, in 1929, as part of its internationalisation strategy, Pirelli (the Italian tyre and cable company) set up a new affiliate in São Paulo to manufacture insulated wiring and cables for power and telecommunications ${ }^{34}$.

During the inter-war years, as the European Allies were rebuilding their own economies after the $1^{\text {st }}$ World War and Germany had many investments confiscated by national authorities in Latin America, we would expect US direct investment to have surpassed European (especially British) direct investment ${ }^{35}$. However, in 1930 more than half of the foreign capital in Brazil was still British, although US participation alone was growing fast, totalling nearly a quarter of FDI in the country during that year ${ }^{36}$. As foreign investment in Brazil was virtually paralysed after the Great Depression of $1929^{37}$, it is reasonable to conclude that Western Europe was the largest foreign direct investor in Brazil up to the $2^{\text {nd }}$ World War, albeit the substantial growth of US direct investment. In fact, in the 1930s very little foreign investment entered in Latin America. As observed by Grosse:

"The stock and flows of direct foreign investment declined as well, due to diminishing market capacities of the [Latin American] countries and also to increased restrictions on the transfer of earnings abroad"38.

\footnotetext{
${ }^{27}$ www.rhodia.com.br/perfil/rhohisto80.htm, História: Anos 20, p.1.

${ }^{28}$ www.bayer.com.br, Empresa: Histórico no Brasil, p.1.

${ }^{29}$ www.bayer.com.br , Empresa: Histórico no Brasil, p.1.

30 www.belgomineira.com.br/content/grupo/historico, Perfil Corporativo, p.1, and Histórico, p.1.

${ }^{31}$ Nestlé, A História da Nestlé, p.3.

${ }^{32}$ www.philips.com.br/inst_hist.jhtml, História da Philips, p.2.

33 www.electrolux.com.br/insitucional/historia.htm, Cronograma Histórico.

34 www.pirelli.com, History in South América.

35 Grosse, Multinationals in Latin América, p.13.

${ }^{36}$ See, among others, R. Gonçalves, Globalização e Desnacionalização, São Paulo: Paz e Terra, 1999, p.55; and

Baer, A Economia Brasileira, pp.231-2.

${ }^{37}$ See, among others, Jones, The Evolution of International Business: An Introduction, pp.44-5; O. D.

Pereira, Multinacionais no Brasil: Aspectos Sociais e Políticos, Rio de Janeiro: Civilização Brasileira, 1975, p.28; S. Topik, A Presença do Estado na Economia Política do Brasil de 1889 a 1930, Rio de Janeiro: Record, 1987, p.193; Baer, A Economia Brasileira, pp.231-2; G. Gereffi and P. Evans, 'Transnational Corporations, Dependent Development, and State Policy in the Semiperiphery: A Comparison of Brazil and Mexico', In: J.L. Dietz (ed.), Latin America's Economic Development: Confronting Crisis, London: Lynne Rienner Publshers, $2^{\text {nd }}$ ed. 1995, pp.203-35.

${ }^{38}$ Grosse, Multinationals in Latin América, p.13.
} 
The Great Depression of the 1930s caused a strong negative impact over the Brazilian exports. The drop in the value of the Brazilian exports and the need of a large amount of foreign currency to finance the external debt, forced the Brazilian government to take drastic measures, such as the suspension of the payment of the external debt and the adoption of currency exchange controls ${ }^{39}$. Moreover, the constitutions of 1934 and 1937 imposed restrictions to the presence of foreign capital in strategic sectors, such as mining, petrol, hydroelectric energy generation and supply, banks, insurance, and maritime and air transport ${ }^{40}$. That was the beginning of the Vargas Era. Under Getúlio Vargas' government (1930 to 1945) coffee bourgeoisie lost its hegemonic political power and was replaced by the emerging industrial class. From then on, industrialization was intensified ${ }^{41}$. Vargas began to pursue policies that supported import substituting industrialization (ISI) and "helped to ensure that there would be domestic demand for manufactured goods by artificially supporting coffee prices $"{ }^{\prime 4}$. The conjunction of these events and measures forced foreign companies to establish in Brazil, a typical "pull" factor.

Despite the difficulties of the 1930s, Western European companies continued to invest in the country. Souza Cruz, for example, opened several plants all over the country, consolidating its leading position in the sector in the 1930 s and $1940 \mathrm{~s}^{43}$. In 1931, Rhodia began manufacturing artificial silk and in 1934 the company opened up a unit of Valisére to produce women's underwear ${ }^{44}$. In 1935, Belgo-Mineira began to build a new mill, which was inaugurated two years later. Besides this new mill, the company continued to invest in the growth of its productive capacity all over the $1930 \mathrm{~s}$ and $1940 \mathrm{~s}^{45}$. At the beginning of the 1930s Unilever began operating in Brazil ${ }^{46}$ and on the eve of the $2^{\text {nd }}$ World War, Siemens began manufacturing transformers in the country ${ }^{47}$.

With the beginning of the $2^{\text {nd }}$ World War, the demand for Latin American's commodities increased, especially by Britain and the USA. However, Latin American economies, including Brazil, were not able to attract noticeable increases in DFI until after the end of the $\mathrm{War}^{48}$. Furthermore, European firms in Brazil suffered the consequences the outbreak of the War in Europe. Bayer, for example, was "nationalised" and operated under the intervention of the army, while the Aliança Comercial de Anilinas was sold to a Brazilian group $^{49}$. Electrolux turned its production to supply the Sweden army ${ }^{50}$, which certainly may have disrupted its commercial operations in Brazil. Imports from the parent company during the war years were suspended and forced Philips in Brazil to survive by selling from electrical engines to insecticides ${ }^{51}$. Rohdia was also forced to diversify its operations in Brazil. In 1942 the company began planting sugar cane to produce alcohol in order to operate its factories in the country. This was the beginning of one of the most important industrial complex of the chemical sector in the country ${ }^{52}$.

\footnotetext{
${ }^{39}$ Baer, A Economia Brasileira, p.50.

${ }^{40}$ Gonçalves, Globalização e Desnacionalização, p.56.

${ }^{41}$ Lacerda, Bocchi, Rego, Borges, and Marques, Economia Brasileira, p.67-74.

${ }^{42}$ Gereffi and Evans, 'Transnational Corporations, Dependent Development, and State Policy in the

Semiperiphery: A Comparison of Brazil and Mexico', pp.207-10.

${ }^{43}$ www.souzacruz.com.br, Perfil Souza Cruz, p.1.

44 www.rhodia.com.br/perfil/rhohisto80.htm, História: Anos 30, pp.1-2.

45 www.belgomineira.com.br/content/grupo/historico, Histórico, pp.1-2.

${ }^{46}$ www.unilever.com/company/unilevertoday, Unilever Business Groups: Foods, Latin América \& Slimfast

Worldwide, 2001, p.1

${ }^{47}$ www.siemens.com , Siemen's History in Brazil.

${ }^{48}$ Grosse, Multinationals in Latin América, p.13.

${ }_{50}^{49}$ www.bayer.com.br, Empresa: Cronologia no Brasil, p.1.

${ }_{50}$ www.electrolux.com.br/institucional/historia.htm, Cronograma Histórico, p.1.

${ }^{51}$ www.philips.com.br/inst hist.jhtml, História da Philips, p.2.

52 www.rhodia.com.br/perfil/rhohisto80.htm, História: Anos 40, p.2.
} 
Thus, from 1914 to late-1930s, European countries continued to be the major investors in Brazil, despite the problems caused by the $1^{\text {st }}$ World War and the Great Depression of the 1930s. Furthermore, new Western European direct investments gradually tended to go to industry instead of public services. They largely contributed to the diversification of the industry in the country, alongside US firms ${ }^{53}$, which became the major investors in Brazil in the 1940s. However, as mentioned before, prior to and during the $2^{\text {nd }}$ World War the participation of foreign companies in the industrial sector was rather limited. During the postwar period, industrialization in Brazil would be the result of a deliberate policy of vertical substitution of imports, in which the role of multinationals would grow enormously.

But the changes in the nature of DFI after the $2^{\text {nd }}$ World War were not restricted to the US supremacy in international business. After the $2^{\text {nd }}$ World War, the developing world lost its relative importance as a host region when compared with the previous period. From then on, DFI increasingly flowed between the developed economies ${ }^{54}$.

By the end of the $2^{\text {nd }}$ World War, US direct investment had already surpassed that of the European taken as a whole ${ }^{55}$ for the first time. Furthermore, US hegemony in the post $-2^{\text {nd }}$ World War resulted in a North American dominance of Brazilian DFI ${ }^{56}$.

\section{From the Post-2 ${ }^{\text {nd }}$ World War to the "Miracle Years"}

In the post- $2^{\text {nd }}$ War period, multinationals would occupy a centre stage in the industrialization of Latin America and stamp their mark on the entire pattern of industrial development of the region, especially after the mid 1950s. Latin America had become an important area of international competition between US and Western European capital ${ }^{57}$.

As mentioned before, US direct investment had become dominant in the Brazilian economy in the 1940s. According to the Brazilian Central Bank, up to 1950 direct foreign investments and reinvestments in Brazil totalled US\$ 307 million, of which nearly a third (US\$ 97,945 million) was from the USA. Moreover, of the new investments in the country (US\$ 183 million), Canada (almost US\$ 94 million) and the USA (US\$ 40 million) together accounted for more than $73 \%{ }^{58}$. In 1951, US direct investment already accounted for nearly $44 \%$ of the total foreign investment in Brazil ${ }^{59}$. However, the years from 1947 to 1954 the net flow of FDI to the country was negative, due to a number of "push" and "pull" factors: the post-war rebuilding of Europe and the changes in the nature of DFI, as mentioned above, by the one side, and the restriction to the remittance of profits, low level of industrialization and income, and the small size of the domestic market, by the other side ${ }^{60}$. Nevertheless, there is evidence of Western European direct investment in the country from the end of the $2^{\text {nd }}$ World War to 1954.

In 1946, the Sweden firm Asea began commercialising automobile lights and dynamos for bicycles ${ }^{61}$. In 1947, Belgo-Mineira started operating its plant to manufacture tubes in João Monlevade, Minas Gerais, and acquired the firm CIMAF - Companhia Industrial e Mercantil de Ferro e Aço, which was founded in 1944. In 1949, Belgo-Mineira inaugurated its hydroelectric mill in João Monlevade and three years later it also acquired the control of

\footnotetext{
${ }^{53}$ Gonçalves, Globalização e Desnacionalização, pp.55-6.

${ }^{54}$ Jones, The Evolution of International Business: An Introduction, p.3.

${ }^{55}$ Baer, A Economia Brasileira, pp.233-4.

${ }^{56}$ Gereffi and Evans, 'Transnational Corporations, Dependent Development, and State Policy in the Semiperiphery: A Comparison of Brazil and Mexico', p.210.

${ }^{57}$ Jenkins, Transnational Corporations and Industrial Transformation in Latin America, pp.25-6

${ }^{58}$ Banco Central do Brasil, Censo de Capitais Estrangeiros: Investimentos e Reinvestimentos Estrangeiros no Brasil, Brasília, May 1998.

${ }^{59}$ C.V. Doellinger and L.C. Cavalcanti, Empresas Multinacionais na Indústria Brasileira, Rio de Janeiro: IPEA/INPES, 1975, p.27.

${ }^{60}$ Gonçalves, Globalização e Desnacionalização, pp.58-9.

${ }^{61}$ www.abb.com./global , 90 Anos de Brasil - 50 Anos de Transferência Tecnológica, p.1.
} 
Samitri - S.A. Mineração Trindade, a mining company ${ }^{62}$, a strategy of vertical integration. In 1948, Philips established a factory to produce illumination products. Two years later, the company started manufacturing radios and in 1953 it began the local manufacturing of televisions ${ }^{63}$. In 1949, Electrolux founded the company Refripar and a year later it began assembling domestic appliances, such as vacuum cleaners ${ }^{64}$. In 1949 , Rhodia established the Companhia Rhodosá de Rayon to produce rayon cloth and began the local production of penicillin $^{65}$. In 1952, the Swiss firm Brown Boveri acquired the control of IBED - Indústria Dínamo Elétrico do Brasil, a manufacturer of small electric engines and transformers ${ }^{66}$. During the same year, Siemens bought a peace of land in São Paulo to build its plant ${ }^{67}$. In 1954, the Sweden firm Asea inaugurated its plant in São Paulo ${ }^{68}$. Finally, also in 1954, Bosch started to manufacture auto parts in Brazil ${ }^{69}$.

Thus, although the decade after the end of the $2^{\text {nd }}$ World War the net flow of DFI to Brazil was negative and US direct investment far exceeded that of Western Europe, several European multinationals were investing in Brazil in new sectors, in expanding their production capacities, and/or in substituting imports from their parent companies.

The year of 1955 marked another turning point of DFI in Brazil. The flow of DFI to the country grew considerably, due to a number of initiatives taken by the Brazilian government to attract foreign capital. Back in 1953, the government had reduced the restrictions to the remittance of profits. Two years later the Brazilian government gave special incentives to foreign investors to import capital goods and established a clear industrial policy, known as the "Plano de Metas", under the Kubitschek's presidency (1956-1960) ${ }^{70}$. Furthermore, policymaking in Brazil decided to replace horizontal ISI, first implemented by Vargas in the late 1930s and early 1940s, by vertical ISI ${ }^{71}$. The objectives of this shift were:

“(...) to broaden the range of local production to include consumer durables, especially the automobile, and to build up local manufacture of the capital and intermediate goods that were causing the big drain on the balance of payments. The investments required were more technologically sophisticated and capital intensive than those required by horizontal ISI, thus making TNCs rather than local capital the most likely instrument."72

Multinationals were ready to respond, mainly because the growth of their investments in the most developed countries, especially in the USA, did not demand all the resources that they commanded ${ }^{73}$. According to the Brazilian Central Bank, direct foreign investments and reinvestments more than tripled in the period from 1951 to $1960^{74}$. Thus, a combination of "pull" and "push" factors was behind the growth of DFI in Brazil after 1955. Furthermore, sector distribution of DFI in Brazil after 1955 went beyond just a concentration in manufacturing, but also within the manufacturing sector DFI was more diverse in term of its

\footnotetext{
${ }_{62}^{6}$ www.belgomineira.com.br/content/grupo/historico_1.asp , Histórico, p.2.

${ }_{64}$ www.philips.com.br/inst_hist.jhtml, História da Philips, p.2.

${ }_{64}$ www.electrolux.com.br/institucional/historia.htm , Cronograma Histórico, p.1.

${ }^{65}$ www.rhodia.com.br/perfil/rhohisto80.htm, História: Anos 40, p.2.

${ }_{66}^{6}$ www.abb.com/global , 90 Anos de Brasil - 50 Anos de Transferência Tecnológica, p.1.

${ }^{67}$ www.siemens.com.br , História, p.1.

68 Ibid., p.1.

${ }^{69}$ www.bosch.com.br/br/boschnobrasil/historia/index.html, Bosch no Brasil, p.3.

70 Gonçalves, Globalização e Desnacionalização, pp.59-61.

${ }^{71}$ Gereffi and Evans, 'Transnational Corporations, Dependent Development, and State Policy in the

Semiperiphery: A Comparison of Brazil and Mexico', pp.207-10.

${ }^{72}$ Ibid., p. 211 .

${ }^{73}$ Ibid., p. 211.

${ }^{74}$ Banco Central do Brasil, Censo de Capitais Estrangeiros: Investimentos e Reinvestimentos Estrangeiros no Brasil, Brasília, May 1998.
} 
origin $^{75}$. Although the USA alone was still responsible for more than $42 \%$ of the total amount, if we take into account just the new investments during this period, US participation was much smaller (nearly 35\%) than that of Western European countries (more than 49\%). Canadian new investments during this period were less than half when compared to the period up to $1950^{76}$.

In 1956, the Brazilian government has introduced a plan aiming at establishing a national automobile industry in the country. The plan restricted imports and obliged multinational automobile companies to opt between abandoning the profitable Brazilian market or to begin, within five years, with the help of fiscal incentives, to manufacture vehicles with 90 to $93 \%$ of national parts. Up to that time, all the vehicles in the country were either imported as complete kits or partially assembled in the country by multinational subsidiaries or even by licensed domestic firms ${ }^{77}$. For several years, beginning in the 1950 s, the Alfa 2000 was built under license as an FNM (the Fábrica Nacional de Motores, a stateowned company, established in the $1940 \mathrm{~s}^{78}$ ). Thus, in 1949 , Volkswagen carried out a survey in the Latin American market, which indicated that Brazil was the best location for the establishment of its first plant outside Germany. In 1953, the company started to assembly the first Beetles, with parts imported from Germany. From 1953 to 1957, Volkswagen produced 2,820 vehicles (2,268 beetles and 552 Kombis). In 1956, Volkswagen decided to build a plant in São Paulo and in the next year the company produced the first Kombis in Brazil, with 50\% of its parts manufactured in the country. In 1959, the company started producing the Beetle, which rapidly became a market success. Then, Volkswagen began to develop local suppliers and in 1961 both Beetle and Kombi used $95 \%$ of national parts ${ }^{79}$.

Other European firms followed the steps of Volkswagen. In 1955, Bayer was back in Brazil with the establishment of Aromatina AS (a fragrance manufacturing company). In the next year (1956), Bayer bought back the Bayer do Brasil and Aliança Comercial de Anilinas, and acquired the Companhia de Ácidos. In 1958, Bayer founded the company Farmaco ${ }^{80}$. In 1955, Philips began the local production of valves, bulbs, and glass components for bulbs. In 1957, the company began producing tube images for TVs and fluorescent bulbs ${ }^{81}$. These investments show clearly that Philips was following a strategy of vertical integration in Brazil. In 1955 also, Rhodia started producing artificial threads and a year later it began building a chemical plant ${ }^{82}$. Two years later, Scania inaugurated its first plant in Latin America, in São Paulo, to produce lorries ${ }^{83}$. During the same year, Brown Boveri inaugurated its first plant in Brazil, employing one thousand workers ${ }^{84}$. In 1959, the German company ZF AG inaugurated its first plant outside Germany to manufacture auto parts ${ }^{85}$.

To sum up, the second half of the 1950s witnessed a new surge of DFI in Brazil due to "pull" and "push" factors. Moreover, DFI was not only substantially larger when compared to the first decade after the end of the $2^{\text {nd }}$ World War, but it was also an important instrument in the vertical strategy of ISI implemented by the Brazilian government. Finally, Western

\footnotetext{
${ }^{75}$ Gereffi and Evans, 'Transnational Corporations, Dependent Development, and State Policy in the Semiperiphery: A Comparison of Brazil and Mexico', p.211.

${ }^{76}$ Banco Central do Brasil, Censo de Capitais Estrangeiros: Investimentos e Reinvestimentos Estrangeiros no Brasil, Brasília, May 1998.

${ }^{77}$ H. Shapiro, 'A Primeira Migração das Montadoras: 1956-1968', In: G. Arbix and M. Zilbovicius (eds.), De

JK a FHC, A Reinvenção dos Carros, São Paulo: Scritta, 1997, p.23.

${ }_{78}^{76 w w . c p d o c . f g v . b r}$, Diretrizes do Estado Novo (1937-1945): Estado e Economia, p.1.

${ }_{79}$ www.volkswagen.com.br/vwbrasil/historia/main.asp , História da Volkswagen no Brasil, p.1.

80 www.bayer.com.br, Cronologia no Brasil, p.1.

81 www.philips.com.br , História da Philips, p.2.

82 www.rhodia.com.br , História: Capítulo IV - Anos 50, p.2.

83 www.scania.com.br , História da Scania na América Latina, p.1.

${ }_{85}$ www.abb.com/global , 90 Anos de Brasil - 50 Anos de Transferência Tecnológica, p.1.

85 www.zf-group.com.br , Histórico, p.1.
} 
European direct foreign investment was regaining its importance it had enjoyed in the pre-war period in the country.

Although the Brazilian economy lost its dynamism in the 1960s, due mainly to successive political crises ${ }^{86}$ DFI nearly doubled during this period. Although the USA was still the largest direct investor in country, its participation in the new investments in Brazil had shrunk to $27.6 \%$ (or US\$ 322,313 million). Even if we take into account Canadian new direct investment (US\$ 91,264 million), North American participation in new DFI in the country accounted for $35.4 \%$ of the total. At the same time, Western European new direct investments in Brazil accounted for $44.6 \%$ (or US\$ 520,594 million) ${ }^{87}$. These figures are corroborated by the fact that in 1967, after the military coup, Brazil had slightly less US DFI than Mexico ${ }^{88}$. Thus, in the 1960s Western European DFI had consolidated its position as the larger foreign direct investor in Brazil, a position it lost only in the 1940s due to the $2^{\text {nd }}$ World War.

The period from 1969 to 1973 was known as the "Brazilian Miracle", under the military regime that took power in 1964 . The new regime had implemented several changes in the Brazilian economy, the results of which started to be felt in $1969^{89}$. Growing rapidly during these years, the Brazilian economy was one of the favourites destinies of direct foreign investment ${ }^{90}$. Furthermore:

"The trend toward increasing US domination of DFI which was evident in the immediate post-World War II period has now reversed itself."

There was now a dispersion of sources of DFI in Brazil, due to changes in the structure of the capitalist world economy, which affected the character of DFI. Brazil was no longer seen simply as a profitable domestic market, but it was treated as an overall strategy of "worldwide sourcing":

"TNC subsidiaries in the semiperiphery play a role more like that of facilities in the core, and yet at the same time their fate is more thoroughly determined by the plans of the parent, since most TNCs manufactured exports from countries like Brazil and Mexico are "intrafirm" sales between affiliated corporate units. The markets in which these subsidiaries sell are now less under the potential control of Brazil and Mexico and more under the administrative control of individual TNCs." 92

Therefore, in 1969, twenty European companies were classified among the top 100 largest business enterprises in Brazil. The ranking was based on an indicator combining net assets and profits, and it included state, domestic, and foreign companies. The 100 largest firms represented almost $72 \%$ of the total net assets of the top 500. Western European firms accounted for more than $10 \%$ of the net assets of the 500 largest firms and more than $14 \%$ of the top 100 firms. Germany was the country that counted with the largest number of firms (4), followed by Britain and France (3); Netherlands, Sweden, and Belgium (2); and Italy, Luxembourg, and Switzerland (1). Finally, Britain and Netherlands also counted with a joint entrepreneurship in the list (Shell). Together, Western European firms represented the largest

\footnotetext{
${ }^{86}$ Baer, Economia Brasileira, pp.87-9.

${ }^{87}$ Banco Central do Brasil, Censo de Capitais Estrangeiros: Investimentos e Reinvestimentos Estrangeiros no Brasil, Brasília, May 1998.

${ }^{88}$ Gereffi and Evans, 'Transnational Corporations, Dependent Development, and State Policy in the Semiperiphery: A Comparison of Brazil and Mexico', p.215.

${ }^{89}$ Baer, Economia Brasileira, pp.89-94.

${ }^{90}$ Amsden, The Rise of the Rest: Challenges to the West from Late-Industrializing Economies.

${ }^{91}$ Gereffi and Evans, 'Transnational Corporations, Dependent Development, and State Policy in the Semiperiphery: A Comparison of Brazil and Mexico', p.215.

${ }^{92}$ Ibid., p. 214.
} 
direct foreign investment in the list of the 100 largest firms in Brazil, although separately no European country matched the United States and Canada, as shown in Table 1. However, in the latter case the Canadian group Light solely represented more than $93 \%$ of the net assets of the Canadian firms ${ }^{93}$. Western European firms were larger (Cr\$ 181,124.3 in net assets), on average, than their US counterparts (Cr\$133,503.7 in net assets) and approximately 83\% of the average size of all foreign firms ranked among the top 100 in Brazil (Cr\$217,674.6 in net assets) in 1969.

Table 1 - The Largest Foreign Firms among the Top 100 in Brazil, by Country, Net Assets (in thousand Cr\$), Percentage of Net Asset over the Top 500 and over the Top 100, in 1969.

\begin{tabular}{|c|c|c|c|c|}
\hline Countries & $\begin{array}{l}\text { No. of } \\
\text { Firms }\end{array}$ & $\begin{array}{l}\text { Net Assets (in } \\
\text { thousand Cr\$) }\end{array}$ & $\begin{array}{l}\text { \% of Net Asset } \\
\text { over Top 500 }\end{array}$ & $\begin{array}{l}\text { \% of Net Asset } \\
\text { over Top } 100\end{array}$ \\
\hline Germany & 4 & 941,711 & 2.67 & 3.71 \\
\hline Britain & 3 & 638,713 & 1.81 & 2.51 \\
\hline France & 3 & 608,952 & 1.72 & 2.40 \\
\hline Netherlands & 2 & 201,293 & 0.57 & 0.79 \\
\hline Sweden & 2 & 185,374 & 0.52 & 0.73 \\
\hline Belgium & 2 & 175,760 & 0.49 & 0.69 \\
\hline Italy & 1 & 335,782 & 0.95 & 1.32 \\
\hline Luxembourg & 1 & 235,217 & 0.66 & 0.92 \\
\hline Britain/Netherlands & 1 & 175,207 & 0.49 & 0.69 \\
\hline Switzerland & 1 & 124,477 & 0.35 & 0.49 \\
\hline Total Europe & 20 & $3,622,486$ & 10.27 & 14,28 \\
\hline United States & 14 & $1,869,053$ & 5.30 & 7.36 \\
\hline Argentina & 4 & 390,654 & 1.10 & 1.54 \\
\hline Canada & 2 & $2,093,785$ & 5.54 & 7.70 \\
\hline Total Rest of the World & 20 & $4,353,492$ & 12.35 & 18.36 \\
\hline Top 100 & 100 & $25,361,972$ & 71.95 & 100.00 \\
\hline Top 500 & 500 & $35,248,528$ & 100.00 & - \\
\hline
\end{tabular}

Source: Adapted from Conjuntura Econômica, Rio de Janeiro: FGV, Vol.24, No. 9, 1970, pp.64-70.

Souza Cruz was the largest European firm in Brazil and second largest private owned company, behind the Canadian Light Serviços de Eletricidade. Souza Cruz was also the third largest private owned company in terms of profits (Cr\$108,651,000), behind Light (Cr\$ $406,887,000)$ and the Brazilian group Votorantin $(\operatorname{Cr} \$ 110,473,000)^{94}$. Volkswagen was the second largest European firm in Brazil by net assets, followed by the French Rhodia and the Italian Pirelli (see Table 2). In terms of profits, Souza Cruz (Cr\$ 108,651,000) was also the largest European firm in Brazil, followed by the Swedish Ericsson (Cr\$ 56,714,000) and Volkswagen (Cr\$ 54,384,000) $)^{95}$.

In terms of sectors, European firms spanned from automobiles, tyres and petrol distribution, to chemicals, tobacco, steel, machinery, textiles, food, construction material, electric appliances, matches and paper. Nevertheless, it is possible to observe a certain industrial specialization among the firms from the different European countries. German firms, for example, were concentrated in the heavy and more capital-intensive industries such as automobiles, steel, and machinery. Apart from Shell, British firms were concentrated in light industries such as tobacco, textiles, and paper, although tobacco required large scales in distribution and promotion. French companies were more diversified in terms of sectors, ranging from chemicals to textiles and material construction. Dutch firms (Philips and Ibrape) were specialized in electric appliances, while Pirelli (Italy) and Nestlé (Switzerland) were major players in tyres and food (see Table 2).

\footnotetext{
${ }^{93}$ Conjuntura Econômica, Rio de Janeiro: FGV, Vol.24, No. 9, 1970, p.64.

${ }^{94}$ Conjuntura Econômica, Rio de Janeiro: FGV, Vol.24, No. 9, 1970, pp.64-5.

95 Conjuntura Econômica, Rio de Janeiro: FGV, Vol.24, No. 9, 1970, pp.64-5.
} 
Thus, in 1969, European firms combined accounted for half of the foreign firms ranked among the top 100 by net assets. Furthermore, they represented more than $45 \%$ of the total net assets held by the 100 largest foreign firms in Brazil. Together, they held almost as much as twice the total of net assets held by the US firms in Brazil. However, this would not last long as the analysis of the 1970s will show. Furthermore, German investment (Cr\$ $941,711,000$ in net assets), the largest among the Europeans, represented nearly half of that of the US.

\section{From the Post-"Miracle Years" to the Lost Decade}

Differently from the case of 1969, the figures for 1975 include the top 550 firms in Brazil: the 500 largest private companies and the 50 largest state-owned. During this year, the largest 100 companies accounted for more than $81 \%$ of the total net assets of the top 550 firms in Brazil. The number of European companies among the top 100 firms had dropped to 16 , a trend that can also be observed in the case of the firms from the rest of the world (they totalled 20 in 1969 and were 15 six years later, as shown in Table 3). This meant that stateowned (jumping from 24 in 1969 to 26 in 1975) and domestic private companies (jumping from 36 in 1969 to 42 in 1975) had grown in number among the top 100 during this period ${ }^{96}$, a conclusion not coherent with the feeling of denationalization of the largest companies in Brazil that prevailed during that time ${ }^{97}$.

Table 3 - The Largest Foreign Firms among the Top 100 in Brazil, in Number of Firms, Net Assets (in thousand Cr\$), Percentage of Net Asset over the Top 500 and over the Top 100, in 1975.

\begin{tabular}{|c|c|c|c|c|}
\hline Countries & $\begin{array}{l}\text { No. of } \\
\text { Firms }\end{array}$ & $\begin{array}{l}\text { Net Assets (in } \\
\text { thousand Cr\$) }\end{array}$ & $\begin{array}{c}\% \text { of Net Asset } \\
\text { over Top } 500\end{array}$ & $\begin{array}{l}\text { \% of Net Asset } \\
\text { over Top } 100\end{array}$ \\
\hline Germany & 4 & $6,781,215$ & 1.97 & 2.42 \\
\hline France & 3 & $2,352,490$ & 0.68 & 0.84 \\
\hline Italy & 2 & $2,373,329$ & 0.69 & 0.84 \\
\hline Switzerland & 2 & $1,419,617$ & 0.41 & 0.50 \\
\hline Britain & 1 & $2,611,785$ & 0.75 & 0.93 \\
\hline Luxembourg & 1 & $1,803,726$ & 0.52 & 0.64 \\
\hline Britain/Netherlands & 1 & $1,467,508$ & 0.42 & 0.52 \\
\hline Netherlands & 1 & 983,354 & 0.28 & 0.35 \\
\hline Belgium & 1 & 522,598 & 0.15 & 0.18 \\
\hline Total Europe & 16 & $20,315,622$ & 5.90 & 7.26 \\
\hline United States & 11 & $8,384,768$ & 2.43 & 2.99 \\
\hline Canada & 2 & $11,211,725$ & 3.26 & 4.00 \\
\hline Argentina & 2 & $1,243,121$ & 0.36 & 0.44 \\
\hline Total Rest of the World & 15 & $20,154,067$ & 5.86 & 7.20 \\
\hline Top 100 & 100 & $279,700,373$ & 81.33 & 100.00 \\
\hline Top 500 & 500 & $343,883,192$ & 100.00 & - \\
\hline
\end{tabular}

Source: Adapted from Exame Melhores \& Maiores, São Paulo: Abril, September 1976, pp.26-47 and Exame

Melhores \& Maiores, São Paulo: Abril, September 1977, pp.34-67.

European firms accounted for 5.9\% of the combined net assets of the top 550 companies in the country and more than $7 \%$ of the top 100, participation that represented nearly half of that found for 1969. However, European firms together were responsible for the

\footnotetext{
${ }^{96}$ Exame Melhores \& Maiores, São Paulo: Abril, September 1976, p.46 and Conjuntura Econômica, Rio de Janeiro: FGV, Vol.24, No. 9, 1970, pp.64-5.

${ }^{97}$ For this debate see, among others, M.C. Tavares, Da Substituição de Importações ao Capitalismo Financeiro: Ensaios sobre Economia Brasileira, Rio de Janeiro: Zahar, $11^{\text {th }}$ ed. 1982; P. Evans, A Tríplice Aliança: as multinacionais, as estatais e o capital nacional no desenvolvimento dependente brasileiro, Rio de Janeiro: Zahar Editores; E. Bacha, Os Mitos de uma Década: Ensaios de Economia Brasileira, Rio de Janeiro: Paz e Terra, $2^{\text {nd }}$ ed. 1978; F. Oliveira, A Economia da Dependência Imperfeita, Rio de Janeiro: Graal, $3^{\text {rd }}$ ed. 1977, pp.76-134; F. Gasparian, Capital Estrangeiro e Desenvolvimento na América Latina: O Mito e os Fatos, Rio de Janeiro: Civilização Brasileira, 1973.
} 
biggest part of the DFI among the top 100 during that year. Nevertheless, as in 1969, no single European country matched the individual participation of both the United States and Canada (see Table 3). On average, European firms (Cr\$ 1,269,726,375 in net assets) were larger than their US counterparts (Cr\$ 762,251,636 in net assets) and nearly $95 \%$ of the average size of the non-European foreign firms in Brazil (Cr\$1,343,604,466 in net assets). However, the figures for the rest of the world are very much influenced by the participation of a single firm (Light, the largest private company in Brazil, in net assets).

Four German companies were among the top 100 companies in net assets in 1975, the largest number of firms per European country: Volkswagen, Mercedes-Benz, Mannesmann, and Krupp. This meant that Germany remained the single largest European investor in Brazil. France followed with 3 firms (Rhodia, Vidraria Santa Marina, and Brasilit), Italy (Pirelli and Sade-Sul) and Switzerland (Nestlé and Ciba-Geigy) with 2, Britain (Souza Cruz), Luxembourg (Belgo-Mineira), Netherlands (Philips), and Belgium (Eletro Cloro) with 1. Shell, the British/Dutch oil firm continued to be ranked among the top 100, but the decrease of British participation is evident. Three British firms ranked among the top 100 in 1969 and only one remained in 1975 (Souza Cruz).

In terms of sectors, we can observe a larger diversification when compared with the late 1960s. Apart from automobiles, steel, machinery, chemicals, textile, tyres, food, tobacco, construction material, electric appliances and paper, firms producing glass and pharmaceutical products also ranked among the top 100, as shown in Table 4.

Table 4 - The Largest European Companies in Brazil, by Country, Sector, and Net Assets, in 1975.

\begin{tabular}{|l|l|l|r|}
\hline \multicolumn{1}{|c|}{ Countries } & \multicolumn{1}{c|}{ Firms } & \multicolumn{1}{c|}{ Nectors } & Assets \\
\hline Germany & Volkswagen do Brasil & Automobile & $2,638,615$ \\
\hline & Mercedes-Benz do Brasil & Automobile & $2,423,841$ \\
\hline & Cia. Siderúrgica Mannesmann & Steel & 987,452 \\
\hline & Krupp Metalurgic Campo Lindo & Machinery & 731,307 \\
\hline & Rhodia Inds. Químicas e Têxteis & Chemicals and Textile & $1,215,697$ \\
\hline & Vidraria Santa Marina & Glass & 596,798 \\
\hline & S.A. Tubos Brasilit & Construction Material & 503,995 \\
\hline Italy & Pirelli & Tyres & $1,723,782$ \\
\hline & Sade-Sul & Construction & 649,547 \\
\hline Switzerland & Nestlé Cia. Indl. e Coml. & Food & 836,467 \\
\hline & Ciba-Geigy & Pharmaceutical & 583,150 \\
\hline Britain & Cia. de Cigarros Souza Cruz & Tobacco & $2,611,785$ \\
\hline Luxembourg & Cia. Siderúrgica Belgo-Mineira & Steel & $1,803,726$ \\
\hline Brit/Netherl. & Shell Brasil S.A. & Petrol Distribution & $1,467,508$ \\
\hline Netherlands & S.A. Philips do Brasil & Electric Appliances & 983,354 \\
\hline Belgium & Inds. Químicas Eletro Cloro & Chemical & 522,598 \\
\hline
\end{tabular}

Source: Adapted from Exame Melhores \& Maiores, São Paulo: Abril, September 1976, pp.26-47 and Exame Melhores \& Maiores, São Paulo: Abril, September 1977, pp.34-67.

If net assets give us a reasonable picture of the size of the firms, it does not give us a picture of market share. Sales are more useful for showing that and tend to be a better indicator of the future of the companies. Therefore, as the figures for sales became available from 1975 onwards, and also due to space considerations, we will use solely this indicator henceforth to analyse the size and importance of European direct investment in Brazil in the following two and half decades.

The ranking of the top 100 largest firms in Brazil by sales in 1975 shows a not very different picture from that of the ranking based on net assets. The sales of the top 100 firms were nearly $60 \%$ of the combined sales of the top 550. Eighteen European companies ranked among the top 100, the same number of US firms. However, the combined sales of the European firms were almost as large as that of the combined sales of all the non-European 
foreign firms (US included). Furthermore, average sales of European firms (Cr\$ $3,649,815,166)$ were substantially larger than the average sales of their US counterparts (Cr\$ $2,624,554,333)$ or that of all the non-European firms (Cr\$ 2,708,419,480). In other words, European multinationals had a larger participation of the Brazilian market. Furthermore, sales of German firms were second only to their US counterparts, as shown in Table 5.

Table 5 - The Largest Foreign Firms among the Top 100 in Brazil, in Number of Firms, Sales (in thousand Cr\$), Percentage of Sales over the Top 500 and over the Top 100, in 1975.

\begin{tabular}{|c|c|c|c|c|}
\hline Countries & $\begin{array}{l}\text { No. of } \\
\text { Firms }\end{array}$ & $\begin{array}{c}\text { Sales (in } \\
\text { thousand Cr\$) }\end{array}$ & $\begin{array}{c}\text { \% of Sales over } \\
\text { Top } 550\end{array}$ & $\begin{array}{c}\text { \% of Sales over } \\
\text { Top } 100\end{array}$ \\
\hline Germany & 4 & $23,721,109$ & 4.42 & 7.50 \\
\hline Britain/Netherlands & 2 & $14,092,579$ & 2.62 & 4.46 \\
\hline Italy & 2 & $5,622,288$ & 1.04 & 1.77 \\
\hline Britain & 2 & $5,062,159$ & 0.94 & 1.60 \\
\hline Switzerland & 2 & $4,470,144$ & 0.83 & 1.41 \\
\hline Sweden & 2 & $3,663,916$ & 0.68 & 1.15 \\
\hline France & 1 & $3,297,127$ & 0.61 & 1.04 \\
\hline Netherlands & 1 & $2,594,000$ & 0.48 & 0.82 \\
\hline Luxembourg & 1 & $2,049,574$ & 0.38 & 0.64 \\
\hline Belgium & 1 & $1,123,777$ & 0.20 & 0.35 \\
\hline Total Europe & 18 & $65,696,673$ & 12.25 & 20.79 \\
\hline United States & 18 & $47,241,978$ & 8.81 & 14.95 \\
\hline Canada & 3 & $12,192,679$ & 2.27 & 3.85 \\
\hline Argentina & 3 & $7,192,830$ & 1.34 & 2.27 \\
\hline Japan & 1 & $1,083,000$ & 0.20 & 0.34 \\
\hline Total Rest of the World & 25 & $67,710,487$ & 12.62 & 21.43 \\
\hline Top 100 & 100 & $315,883,192$ & 58.91 & 100.00 \\
\hline Top 550 & 550 & $536,141,863$ & 100.00 & - \\
\hline
\end{tabular}

Source: Adapted from Exame Melhores \& Maiores, São Paulo: Abril, September 1976, pp.26-47 and Exame

Melhores \& Maiores, São Paulo: Abril, September 1977, pp.34-67.

The largest European firms in Brazil by sales were mostly concentrated in the heavy, technology and capital-intensive sectors. The only exception was Peg-Pag, a British chain of supermarkets. Again, British firms were very much represented by firms in lighter industries or non-financial services, as happened in 1969 when a textile (Linhas Corrente) and a paper (Pirahy) firm ranked among the top British firms in Brazil. German firms continued to dominate the rank of the largest European firms either in numbers or sales. Volkswagen was the second largest company in Brazil by sales, behind the state-owned oil company Petrobrás ${ }^{98}$. Among the Europeans, Volkswagen was followed by Shell and Mercedes-Benz.

To sum up, Western European direct investment was the most important in Brazil in 1975. Western European firms were larger, on average, either in net assets or sales. They also numbered almost half of the largest foreign firms in Brazil and Germany continued to be the largest single Western European investor. Nevertheless, at the beginning of the 1980s their prominence was be challenged by US firms.

In 1980, the 100 largest firms by sales in Brazil accounted for more than $60 \%$ of the sales of the top 550. Twenty-one European firms ranked among the top 100, against 20 from the rest of the world. Compared with the figures for 1975, European firms grew in number in detriment of the firms from the rest of the world, since the overall number of foreign firms among the top 100 had decreased in 1980 (from 43 in 1975 to 41 in 1980). Together, European firms were the largest investors in Brazil, although, once more, separately none European country matched the United States. However, the power of US firms had increased since 1975. This can be best illustrated by the comparison of average sales. On average, sales

\footnotetext{
${ }^{98}$ Exame Melhores \& Maiores, São Paulo: Abril, September 1976, pp.26-47.
} 
of European firms amounted to $\mathrm{Cr} \$ 41,866,204,140$, while that of their US counterparts amounted to Cr\$43,155,950,680. Nevertheless, European companies were still above average, since the sales of the firms comprising the rest of the world (US included) amounted to $\mathrm{Cr} \$ 39,218,041,800$. Thus, in comparison to their relative sales in 1975, European firms had shrunk relatively to the US multinationals in Brazil. But, the importance of European direct investment in Brazil in 1980 is undisputable, although US firms were growing and getting larger.

The number of German firms (7) among the top 100 in 1980 increased when compared with 1975 (4). German firms had also grown into sectors like electronics (AEG Telefunken) and auto-parts (Bosch), as shown in Table 8. However, Shell was the largest European firm in sales. British participation had shrunk to Souza Cruz, still one of the largest European multinationals in Brazil. Fiat, the Italian automobile manufacturer, ranked for the first time among the largest firms following its establishment in the second half of the 1970s. Makro also ranked for the first time among the largest Dutch firms, as it did Saab-Scania among the Swedish firms. Gessy Lever, a Unilever subsidiary and also a British and Dutch joint entrepreneurship, ranked among the top 100 for the first time too.

European largest firms in Brazil continued to take advantage of scales of production, capital, technology, distribution and promotion (see Table 8). In the non-financial service sector, the Dutch giant wholesaler Makro replaced the British retailer Peg-Pag. Thus, as European direct investment in Brazil grew and became more diversified, it was challenged by US multinationals in the country. However, as European firms would overcome US firms in the early 1990s this suggests that either they were influenced by different business cycles at home or different factors were behind their investment decisions in Brazil.

\section{The 1990s}

In 1990, the largest 100 firms in Brazil accounted for more than 58\% of the sales of the top 550. European firms represented almost $13 \%$ of the sales of the 550 largest companies in the country and nearly $23 \%$ of the top 100 (see Table 9). However, comparison between European and US firms in the early 1990s is not easy because the joint-venture between Ford and Volkswagen, to form Autolatina, the largest private company and the second largest among the top 550, blurs the analysis. As Volkswagen became the largest partner in the joint venture we decided to count Autolatina as an European direct investment, which of course is not true. However, even if we split Autolatina in two and count half of it as US investment and the other half as European, the conclusion does not change. On average, European firms were once more larger than US firms. Counting Autolatina as European, they averaged US\$ 1,451,5 millions, while their US counterparts averaged US\$ 1,135.4 millions. Counting Autolatina as half European and half US, the former ones averaged US\$ 1,291.8 millions and the latter ones US\$1,267.1 millions ${ }^{99}$. Furthermore, it is interesting to note that in 1990 the largest multinationals by sales were almost solely Europeans or US firms, as shown in Table 9. This is an undisputable evidence of the importance of US and, specially, Western European direct foreign investment in Brazil.

Germany continued to hold the largest number of firms among the top 100 ( 3 if we do not count Autolatina). Although the Dutch Philips do Brasil and Philips Amazônia were, in fact, the same firm, Shell and Gessy Lever were both British and Dutch. Italy, Switzerland, and France had two companies each. The French retailer Carrefour was the new entrant in the list, and together with the Dutch wholesaler Makro they were becoming major players in the non-financial service. This points to a smaller concentration in terms of countries among the largest Western European firms in Brazil, as shown in Table 9.

Thus, Western European firms in 1990 were slightly larger than their US counterparts, a position they had lost in 1980. Furthermore, their distribution among the largest Western

\footnotetext{
${ }^{99}$ Exame Melhores \& Maiores, São Paulo: Abril, August 1991, pp.46-69.
} 
European economies was less concentrated, a trend that should deepen in the end of the 1990s. Finally, Western European and US firms dominated DFI among the top 100 firms in Brazil, a trend already observed in the recent past and that would continue to take place at the beginning of the new century.

Table 9 - The Largest Foreign Firms among the Top 100 in Brazil, in Number of Firms, Sales (in thousand US\$), Percentage of Sales over the Top 500 and over the Top 100, in 1990.

\begin{tabular}{|c|c|c|c|c|}
\hline Countries & $\begin{array}{l}\text { No. of } \\
\text { Firms } \\
\end{array}$ & $\begin{array}{c}\text { Sales (in } \\
\text { thousand US\$) }\end{array}$ & $\begin{array}{c}\text { \% of Sales over } \\
\text { Top } 550 \\
\end{array}$ & $\begin{array}{c}\text { \% of Sales over } \\
\text { Top } 100 \\
\end{array}$ \\
\hline Germany & 3 & $2,375.5$ & 1.22 & 2.10 \\
\hline Netherlands & 3 & $2,263.0$ & 1.17 & 2.00 \\
\hline Britain/Netherlands & 2 & $4,775.1$ & 2.47 & 4.22 \\
\hline Switzerland & 2 & $2,078.5$ & 1.07 & 1.83 \\
\hline Italy & 2 & $1,892.4$ & 0.97 & 1.67 \\
\hline France & 2 & $2,470.2$ & 1.27 & 2.18 \\
\hline Germany/US & 1 & $5,430.9$ & 2.81 & 4.80 \\
\hline Britain & 1 & $2,890.6$ & 1.49 & 2.55 \\
\hline Sweden & 1 & 500.0 & 0.25 & 0.44 \\
\hline Total Europe & 17 & $24,676.2$ & 12.77 & 21.82 \\
\hline United States & 11 & $12,490.4$ & 6.46 & 11.04 \\
\hline Canada & 1 & 497.6 & 0.25 & 0.44 \\
\hline Argentina & 1 & 534.0 & 0.27 & 0.47 \\
\hline Total Rest of the World & 13 & $13,522.0$ & 6.99 & 11.96 \\
\hline Top 100 & 100 & $113,039,6$ & 58.51 & 100.00 \\
\hline Top 550 & 550 & $193,186.1$ & 100.00 & - \\
\hline
\end{tabular}

Source: Adapted from Exame Melhores \& Maiores, São Paulo: Abril, August 1991, pp.46-69.

The 1990s was a decade of big transformations in the Brazilian economy. Privatisation of state-owned companies, monetary stabilization with the implementation of the Real Plan, the creation of Mercosul, and the more opened outlook of the economic policy, combined with a favourable influx of foreign investment towards the so-called "emerging economies", has brought a new wave of DFI into the economy. Western European firms have played a major role in this new movement, as we can see from the analysis of the top 100 firms in the year 2000 .

In 2000, the sales of the top 100 largest firms totalled almost $58 \%$ of the sales of the top 550, as shown in Table 11. Twenty-nine European firms ranked among the top 100 (a number that has nearly doubled since 1990 when they were 17), while foreign firms from the rest of the world totalled twenty four (United States 19, Argentina 2, Canada, Japan, and Chile (1). The sales of the largest European firms represented more than $16 \%$ of the sales of the top 550 (against nearly $12 \%$ for foreign firms from the rest of the world) and nearly $29 \%$ of the sales of the top 100. Among the largest foreign firms in Brazil in 2000, by sales, another 24 were from the. The combined sales of the represented of the sales of the top 550 and approximately $20 \%$ of the sales of the top 100 . Thus, the comparison of the figures for Europe and the rest of the world show clearly the importance of European capital in 2000. Furthermore, the growth of foreign firms among the largest 100 companies in Brazil is also undisputable and a strong evidence of the denationalization of the Brazilian domestic largest firms. On average, the sales of European firms (US\$1,994.6 millions) were larger than that of the firms from the rest of the world (US\$ 1,705.4 millions) and from the United States (US\$ 1,882.7 millions $)^{100}$. However, no European country matched the United States, the single largest investor in Brazil, with 19 firms among the top 100, totalling US\$ 57,843.8 millions in sales.

${ }^{100}$ Exame Melhores \& Maiores, São Paulo: Abril, July 2001, pp.84-109. 
Italy and France equalled Germany in the number of foreign firms among the top 100, with five each. The three were now the largest Western European investors in the Brazil. Spain, Portugal, and Finland were the new Western European countries with large direct investments in the country. Apart from the two joint entrepreneurships with the Dutch, British participation among the top 100 remained restricted to one firm (Souza Cruz). Some countries presented a portfolio of investments more diversified than others. French investment, for example, spanned from retailing and textiles to automobiles, steel, energy and chemicals. Italian interests were also diversified, with investments in sectors like automobiles, telecommunications, petrol distribution, food, and tyres. German firms, on the other hand, remained more concentrated in automobiles, chemicals, electronics, and auto-parts. Apart from Shell and Gessy Lever, Dutch firms were even more concentrated in the non-financial sectors: retailing and wholesaling. Finally, Spanish firms were prominent in public utilities, such as telecommunications and energy.

Table 11 - The Largest Foreign Firms among the Top 100 in Brazil, in Number of Firms, Sales (in thousand US\$), Percentage of Sales over the Top 500 and over the Top 100, in 2000.

\begin{tabular}{|c|c|c|c|c|}
\hline Countries & $\begin{array}{l}\text { No. of } \\
\text { Firms }\end{array}$ & $\begin{array}{c}\text { Sales (in thousand } \\
\text { US\$) }\end{array}$ & $\begin{array}{c}\text { \% of Sales over } \\
\text { Top } 550\end{array}$ & $\begin{array}{c}\text { \% of Sales over } \\
\text { Top } 100\end{array}$ \\
\hline Germany & 5 & $11,690.5$ & 3.34 & 5.81 \\
\hline France & 5 & $9,645.7$ & 2.76 & 4.80 \\
\hline Italy & 5 & $8,653.3$ & 2.47 & 4.30 \\
\hline Spain & 3 & $6,911.0$ & 1.97 & 3.43 \\
\hline Britain/Netherlands & 2 & $7,092.0$ & 2.03 & 3.53 \\
\hline Portugal & 2 & $3,507.3$ & 1.00 & 1.74 \\
\hline Netherlands & 2 & $2,192.1$ & 0.62 & 1.09 \\
\hline Sweden & 2 & $1,845.6$ & 0.52 & 0.91 \\
\hline Britain & 1 & $2,790.5$ & 0.79 & 1.38 \\
\hline Switzerland & 1 & $2,574.8$ & 0.73 & 1.28 \\
\hline Finland & 1 & 941.0 & 0.26 & 0.46 \\
\hline Total Europe & 29 & $57,843.8$ & 16.56 & 28.79 \\
\hline United States & 19 & $35,772.4$ & 10.24 & 17.80 \\
\hline Argentina & 2 & $2,687.5$ & 0.76 & 1.33 \\
\hline Canada & 1 & 903.0 & 0.25 & 0.44 \\
\hline Japan & 1 & 844.7 & 0.24 & 0.42 \\
\hline Chile & 1 & 724.3 & 0.20 & 0.36 \\
\hline Total Rest of the World & 24 & $40,931.9$ & 11.72 & 20.37 \\
\hline Top 100 & 100 & $200,904.8$ & 57.53 & 100.00 \\
\hline Top 550 & 550 & $349,179,9$ & 100.00 & - \\
\hline
\end{tabular}

Source: Adapted from Exame Melhores \& Maiores, São Paulo: Abril, July 2001, pp.84-109.

Volkswagen was the largest private company in Brazil by sales, followed by the Spanish Telefônica. Carrefour was the fourth largest private company (behind the US General Motors) and Shell the sixth (behind the also US Embratel). Finally, Fiat ranked eightieth, behind the Brazilians Pão de Açúcar and Ipiranga. Thus, five Western European firms ranked among the ten largest private companies. However, the state-owned oil company, Petrobras, was by far the largest company in Brazil with sales of almost 40 billion dollars in 2000. It is also interesting to note the larger number of European firms in public utilities, a return to the pattern of investment Western European capital had in the $19^{\text {th }}$ century.

\section{Conclusion}

Following a long historical experience in Brazil, European direct investment has been one of the largest in the country for most of the period from the mid 1800s to 2000. Only the USA challenged European predominance in direct foreign investments in the Brazilian economy, first in the 1940 s and later in the last three decades of the $20^{\text {th }}$ century, although a more careful study on Japanese direct investment must be carried out. Among Europeans, 
German firms have dominated, although in 2000 Italian and French investments has equalled the participation of the Germans among the 100 largest firms in Brazil. Following the opening of the Brazilian economy in the 1990s, European direct investment not only grew, but also spread into a number of different sectors. Furthermore, firms from new different European countries, such as Spain, Portugal, and Finland, ranked among the top 100, diversifying European direct investment in the country. Finally, the study of DFI for the last 140 years in Brazil has shown that two basic factors were very much important: history and culture. The importance of European DFI in Brazil during almost a century and a half cannot be understood only by the importance of this region in the world economy. Brazilian economy (as well as that of most of Latin America) was a historical extension of the European economy. Different from other continents, most of Latin America was a quasi-virgin area, in economic terms, when Europeans first arrived. Since the beginning, Brazil (and, to a large extent, Latin America) was part of the European economy and this has facilitated European business in the region. Europeans did not had to face an established society and economy. On the contrary, they have shaped both the economy and the culture of the region, as immigrants from Western Europe largely constituted the population of the region. Thus, the cultural links are obvious. Therefore, this should not be under estimated when analysing DFI in Brazil (and Latin America). 


\section{Appendix}

Table 2 - The Largest European Companies in Brazil, by Country, Sector, and Net Assets, in 1969.

\begin{tabular}{|l|l|l|r|}
\hline \multicolumn{1}{|c}{ Countries } & \multicolumn{1}{|c|}{ Firms } & \multicolumn{1}{c|}{$\begin{array}{c}\text { Nect Assets } \text { (in } \\
\text { thousand Cr\$) }\end{array}$} \\
\hline Germany & Volkswagen do Brasil & Automobile & 454,368 \\
\hline & Mercedes-Benz do Brasil & Automobile & 288,791 \\
\hline & Cia. Siderúrgica Mannesmann & Steel & 96,134 \\
\hline & Krupp Metalurgic Campo Lindo & Machinery & 102,418 \\
\hline Britain & Souza Cruz & Tobacco & 495,992 \\
\hline & Linhas Corrente & Textile & 78,740 \\
\hline & Cia. Industrial Papel Pirahy & Paper & 63,981 \\
\hline France & Rhodia & Chemicals and Textile & 444,100 \\
\hline & S.A. Tubos Brasilit & Construction Material & 88,756 \\
\hline & Rhodosá Inds. Têxteis & Textile & 76,096 \\
\hline Netherlands & S.A. Phillips do Brasil & Electric Appliances & 134,025 \\
\hline & Ibrape & Electric Appliances & 67,268 \\
\hline Sweden & Ericsson do Brasil Com. e Ind. & Electric Appliances & 118,970 \\
\hline & Cia. Fiat Lux & Matches & 66,404 \\
\hline Belgium & Inds. Químicas Eletro Cloro & Chemical & 122,116 \\
\hline & Eternit do Brasil & Construction Material & 53,644 \\
\hline Italy & Pirelli S.A.Cia. Ind. Brasileira & Tyres & 335,782 \\
\hline Luxembourg & Cia. Siderúrgica Belgo-Mineira & Steel & 235,217 \\
\hline Brit/Netherl. & Shell Brasil S.A. & Petrol Distribution & 175,207 \\
\hline Switzerland & Nestlé Cia. Indl. e Coml. & Food & 124,477 \\
\hline Source: Adap
\end{tabular}

Source: Adapted from Conjuntura Econômica, Rio de Janeiro: FGV, Vol.24, No. 9, 1970, pp.64-5.

Table 6 - The Largest European Companies in Brazil, by Country, Sector, and Sales (in thousand Cr\$), in 1975.

\begin{tabular}{|l|l|l|r|}
\hline \multicolumn{1}{|c|}{ Countries } & \multicolumn{1}{c|}{ Firms } & \multicolumn{1}{c|}{ Sectors } \\
\hline & Volkswagen do Brasil & Automobile & $14,316,013$ \\
\hline & Mercedes-Benz do Brasil & Automobile & $6,005,627$ \\
\hline & Cia. Siderúrgica Mannesmann & Steel & $2,114,294$ \\
\hline & Bayer & Pharmaceutical & $1,285,175$ \\
\hline & Pirelli & Tyres & $4,089,288$ \\
\hline & Olivetti & Office Equipment & $1,573,000$ \\
\hline Switzerland & Nestlé Cia. Indl. e Coml. & Food & $3,327,118$ \\
\hline & Ciba-Geigy & Pharmaceutical & $1,143,026$ \\
\hline Britain & Cia. de Cigarros Souza Cruz & Tobacco & $3,899,073$ \\
\hline & Peg-Pag & Retail & $1,163,086$ \\
\hline Brit/Netherl. & Shell Brasil S.A. & Petrol Distribution & $12,476,501$ \\
\hline & Gessy Lever & Cleaning and Hygiene & $1,616,078$ \\
\hline Sweden & Ericsson & Electric Appliances & $2,345,986$ \\
\hline & Saab-Scania & Automobile & $1,317,930$ \\
\hline France & Rhodia Inds. Químicas e Têxteis & Chemicals and Textile & $3,297,127$ \\
\hline Luxembourg & Cia. Siderúrgica Belgo-Mineira & Steel & $2,049,574$ \\
\hline Netherlands & S.A. Philips do Brasil & Electric Appliances & $2,594,000$ \\
\hline Belgium & Inds. Químicas Eletro Cloro & Chemical & $1,123,777$ \\
\hline Source: Adap
\end{tabular}

Source: Adapted from Exame Melhores \& Maiores, São Paulo: Abril, September 1976, pp.26-47 and Exame

Melhores \& Maiores, São Paulo: Abril, September 1977, pp.34-67. 
Table 7 - The Largest Foreign Firms among the Top 100 in Brazil, in Number of Firms, Sales (in thousand Cr\$), Percentage of Sales over the Top 500 and over the Top 100, in 1980.

\begin{tabular}{|c|c|c|c|c|}
\hline Countries & $\begin{array}{l}\text { No. of } \\
\text { Firms }\end{array}$ & $\begin{array}{c}\text { Sales (in } \\
\text { thousand Cr\$) }\end{array}$ & $\begin{array}{c}\text { \% of Sales over } \\
\text { Top } 550\end{array}$ & $\begin{array}{c}\text { \% of Sales over } \\
\text { Top } 100\end{array}$ \\
\hline Germany & 7 & $265,497,769$ & 3.57 & 5.78 \\
\hline Britain/Netherlands & 2 & $207,686,785$ & 2.79 & 4.52 \\
\hline Italy & 2 & $91,552,426$ & 1.23 & 1.99 \\
\hline Switzerland & 2 & $54,408,775$ & 0.73 & 1.18 \\
\hline France & 2 & $49,819,724$ & 0.67 & 1.08 \\
\hline Netherlands & 2 & $47,199,727$ & 0.63 & 1.02 \\
\hline Britain & 1 & $124,062,434$ & 1.67 & 2.70 \\
\hline Luxembourg & 1 & $21,891,128$ & 0.29 & 0.47 \\
\hline Sweden & 1 & $17,101,477$ & 0.23 & 0.37 \\
\hline Total Europe & 21 & $879,190,245$ & 11.83 & 19.15 \\
\hline United States & 16 & $690,495,211$ & 9.29 & 15.04 \\
\hline Canada & 2 & $37,527,040$ & 0.50 & 0.81 \\
\hline Argentina & 1 & $40,634,000$ & 0.54 & 0.88 \\
\hline Japan & 1 & $15,974,585$ & 0.21 & 0.34 \\
\hline Total Rest of the World & 20 & $784,360,836$ & 10.55 & 17.08 \\
\hline Top 100 & 100 & $4,590,445,475$ & 61.79 & 100.00 \\
\hline Top 550 & 550 & $7,428,015,367$ & 100.00 & - \\
\hline
\end{tabular}

Source: Adapted from Exame Melhores \& Maiores, São Paulo: Abril, September 1980, pp.34-71.

Table 8 - The Largest European Companies in Brazil, by Country, Sector, and Sales (in thousand Cr\$), in 1980.

\begin{tabular}{|l|l|l|r|}
\hline \multicolumn{1}{|c|}{ Countries } & \multicolumn{1}{c|}{ Firms } & \multicolumn{1}{c|}{ Sales } \\
\hline Germany & Volkswagen do Brasil & Automobile & $110,093,032$ \\
\hline & Mercedes-Benz do Brasil & Automobile & $68,431,434$ \\
\hline & Cia. Siderúrgica Mannesmann & Steel & $25,788,674$ \\
\hline & Bayer & Pharmaceutical & $16,783,631$ \\
\hline & Bosch & Auto Parts & $16,400,000$ \\
\hline & AEG Telefunken & Electronics & $14,359,021$ \\
\hline & Hoechst & Chemical/Pharmaceuticals & $13,641,977$ \\
\hline Italy & Pirelli & Tyres & $54,463,558$ \\
\hline & Fiat & Automobile & $37,088,868$ \\
\hline Switzerland & Nestlé Cia. Indl. e Coml. & Food & $39,651,025$ \\
\hline & Ciba-Geigy & Pharmaceutical & $14,757,750$ \\
\hline Brit/Netherl. & Shell Brasil S.A. & Petrol Distribution & $183,268,408$ \\
\hline & Gessy Lever & Cleaning and Hygiene & $24,418,377$ \\
\hline France & Rhodia Inds. Químicas e Têxteis & Chemicals and Textile & $35,891,264$ \\
\hline & Vidraria Santa Marina & Glass & $13,928,460$ \\
\hline Netherlands & S.A. Philips do Brasil & Electric Appliances & $25,939,000$ \\
\hline & Makro & Wholesale & $21,260,727$ \\
\hline Luxembourg & Cia. Siderúrgica Belgo-Mineira & Steel & $21,891,128$ \\
\hline Britain & Souza Cruz & Tobacco & $124,062,434$ \\
\hline Sweden & Saab-Scania & Automobile & $17,101,477$ \\
\hline Source: Adapa &
\end{tabular}

Source: Adapted from Exame Melhores \& Maiores, São Paulo: Abril, September 1980, pp.34-71. 
Table 10 - The Largest European Companies in Brazil, by Country, Sector, and Sales (in thousand US\$), in 1990.

\begin{tabular}{|l|l|l|r|}
\hline \multicolumn{1}{|c|}{ Countries } & \multicolumn{1}{c|}{ Sectors } & \multicolumn{1}{c|}{ Sales } \\
\hline Germany & Mercedes-Benz do Brasil & Automobile & $1,419.8$ \\
\hline & Hoechst & Chemical and Pharmaceuticals & 536.4 \\
\hline & Bayer & Pharmaceutical & 419.3 \\
\hline Netherlands & Philips do Brasil & Electric Appliances & $1,075.7$ \\
\hline & Makro & Wholesale & 683.6 \\
\hline & Philips da Amazônia & Electric Appliances & 503.7 \\
\hline Italy & Fiat & Automobile & $1,291.6$ \\
\hline & Pirelli & Tyres & 600.8 \\
\hline Switzerland & Nestlé & Food & $1,609.9$ \\
\hline & Ciba-Geigy & Pharmaceutical & 468.6 \\
\hline Brit/Netherl. & Shell & Petrol Distribution & $3,142.3$ \\
\hline & Gessy Lever & Cleaning and Hygiene & $1,632.8$ \\
\hline France & Carrefour & Retail & $1,832.4$ \\
\hline & Rhodia & Chemical and Textile & 673.8 \\
\hline Germany/US & Autolatina* & Automobile & $5,430.9$ \\
\hline Britain & Souza Cruz & Tobacco & $2,890.6$ \\
\hline Sweden & Saab-Scania & Automobile & 500.0 \\
\hline
\end{tabular}

Source: Adapted from Exame Melhores \& Maiores, São Paulo: Abril, August 1991, pp.46-69.

*This was a joint-venture between the German Volkswagen and the US Ford.

Table 12 -The Largest European Companies in Brazil, by Country, Sector, and Sales (in thousand US\$), in 2000

\begin{tabular}{|c|c|c|c|}
\hline Countries & Firms & Sectors & Sales \\
\hline \multirow[t]{5}{*}{ Germany } & Volkswagen do Brasil & Automobile & $5,738.5$ \\
\hline & DaimlerChrysler & Automobile & $2,171.3$ \\
\hline & Basf & Chemical & $1,420.3$ \\
\hline & Siemens & Electronics & $1,410.8$ \\
\hline & Bosch & Autoparts & 949.6 \\
\hline \multirow[t]{5}{*}{ France } & Carrefour & Retail & $4,821.5$ \\
\hline & Light & Energy & $2,131.4$ \\
\hline & CST & Steel & $1,106.4$ \\
\hline & Renault & Automobile & 838.2 \\
\hline & Rhodia & Chemical & 748.2 \\
\hline \multirow[t]{5}{*}{ Italy } & Fiat & Automobile & $3,730.2$ \\
\hline & Brasil Telecom & Telecommunications & $2,722.2$ \\
\hline & Pirelli & Tyres & 754.0 \\
\hline & Parmalat & Food & 731.6 \\
\hline & Agip & Petrol Distribution & 715.3 \\
\hline Switzerland & Nestlé & Food & $2,574.8$ \\
\hline \multirow[t]{3}{*}{ Spain } & Telefônica & Telecommunications & $5,128.7$ \\
\hline & Telefônica Celular & Telecommunications & 949.7 \\
\hline & Coelba & Energy & 832.6 \\
\hline Britain & Souza Cruz & Tobacco & $2,790.5$ \\
\hline \multirow[t]{2}{*}{ Portugal } & Telesp Celular & Telecommunications & $1,968.9$ \\
\hline & Sonae & Retail & $1,538.4$ \\
\hline \multirow[t]{2}{*}{ Brit/Netherl. } & Shell & Petrol Distribution & $4,457.6$ \\
\hline & Unilever & Hygiene & $2,634.4$ \\
\hline \multirow[t]{2}{*}{ Netherlands } & Makro & Wholesale & $1,110.8$ \\
\hline & Bompreço & Retail & $1,081.3$ \\
\hline Sweden & Ericsson & Electronics & $1,845.6$ \\
\hline Finland & Nokia & Electronics & 941.0 \\
\hline
\end{tabular}

Source: Adapted from Exame Melhores \& Maiores, São Paulo: Abril, July 2001, pp.84-109. 